\title{
Assessment of early survival and growth of planted Scots pine (Pinus sylvestris) seedlings under extreme continental climate conditions of northern Mongolia
}

\author{
Gerelbaatar Sukhbaatar ${ }^{1,2}$ - Batsaikhan Ganbaatar ${ }^{3}$ - Tsogtbaatar Jamsran ${ }^{3}$. \\ Battulga Purevragchaa $^{3} \cdot$ Baatarbileg Nachin ${ }^{2} \cdot$ Alexander Gradel $^{4,5}$
}

Received: 19 October 2018/Accepted: 6 January 2019/Published online: 6 April 2019

(C) The Author(s) 2019

\begin{abstract}
Environmental factors play vital roles in successful plantation and cultivation of tree seedlings. This study focuses on problems associated with reforestation under extreme continental climatic conditions. The objectives were to assess relative seedling performance (survival and growth) with respect to plantation age, and to analyze the influence of specific climatic factors during the early stages of Scots pine (Pinus sylvestris L.) plantations. The study was carried out in reforested areas of the Tujyin Nars
\end{abstract}

Project funding: The work was supported by the Partnerships for Enhanced Engagement in Research (PEER) Science Cycle 2 Grant \#296 Building research and teaching capacity to aid climate change and natural resource management at the National University of Mongolia (NUM)'.

The online version is available at http://www.springerlink.com

Corresponding editor: Tao Xu.

Alexander Gradel

agradel@mail.de

1 Department of Environment and Forest Engineering, National University of Mongolia, Ulaanbaatar 14201, Mongolia

2 Institute of Forest, National University of Mongolia, Ulaanbaatar 14201, Mongolia

3 Division of Forest Resources and Protection, Institute of Geography and Geoecology, Mongolian Academy of Sciences, Ulaanbaatar 15710, Mongolia

4 Faculty of Forest Sciences and Forest Ecology, Universität Göttingen, Büsgenweg 5, 37077 Göttingen, Germany

5 Chair of Forest Policy, Forest Economy and Forest Management, Institute of Management and Economy of the Forest Sector, Saint Petersburg State Forest Technical University, Institutskii per., 5, 194021 Saint Petersburg, Russia region of northern Mongolia on six Scots pine plantations ranging from 5 to 10 years. In each of the six plantations, five $900 \mathrm{~m}^{2}$ permanent sample plots were established and survival rates and growth performance measured annually over 7 years. Results show high variation in survival among the plantations $(p<0.001, \mathrm{~F}=29.7)$. Seedling survival in the first year corresponded directly to the number of dry days in May. However, survival rate appeared to stabilize after the second year. The insignificant variation of height categories throughout the observation period indicated low competition among individuals. Two linear mixed-effect models show that height and radial growth were best explained by relative air humidity, which we consider to be a reliable indicator of site-specific water availability. Insufficient amounts and uneven distribution of rainfall pose a major threat during the first year of plantation establishment. Humidity and water availability are decisive factors for a successful seedling plantation. This highlights the impact of drought on forest plantations in northern Mongolia and the importance of developing climate resilient reforestation strategies.

Keywords Reforestation - Scots pine - Pinus sylvestris L. . Survival · Increment $\cdot$ Growth $\cdot$ Climate $\cdot$ Mongolia

\section{Introduction}

Forest plantations provide a range of benefits, including playing a key role in ecosystem functionality (Hector and Bagchi 2007), offsetting continuing deforestation and degradation (FAO 2010), providing carbon sequestration (Kongsager et al. 2013) and storage (Chen et al. 2015), promoting efficient nutrient cycling (Ma et al. 2007), 
increasing plant species diversity and community structure (Eycott et al. 2006), and preventing soil erosion (Lawson and Michler 2014). Forested areas regulate streamflow and modify the magnitude of peak flows (Buendia et al. 2015), and improve soil water retention (Kahle et al. 2005). The benefits of establishing plantations in specific areas of open land are therefore twofold, in that they meet increasing demands for timber by reducing deforestation (Pirard et al. 2016), but also strengthen local ecosystem functions. However, it can be difficult to establish forest plantations in dry, continental regions. A number of previous studies have shown that changes in seedling survival rates and growth performance may be due to limited light availability (Kunstler et al. 2005; Hattori et al. 2009), nutrient deficiencies (Oscarsson et al. 2006; Löf et al. 2007), interspecific competition (Osunkoya et al. 2005), and changing environmental factors (Soehartono et al. 2002; Battles et al. 2008; Hattori et al. 2013). Establishing plantations on logged-over land, previously dominated by conifers, with seedlings of native species is one way to accelerate forest recovery mechanisms. However, Löf et al. (2007) reported that the mortality of seedlings planted on open sites is higher than seedlings planted under a native tree canopy.

Mongolia has relatively low amount of forest resources. Forest cover represents roughly $7-8 \%$ of the territory; the most recent National Forest Inventory (MPNFI 2016) reported that boreal forest cover is nearly 9.1 million hectares $(<6 \%)$ and is found in the transitional zone between the Siberian boreal forest and the Central Asian dry steppe (Mühlenberg et al. 2012). This transitional zone is characterized by a highly continental climate with dry winters. Forests in Mongolia mainly grow on mountain slopes between 700 and $2500 \mathrm{~m}$ a.s.l. World Bank studies (Crisp et al. 2004; Mühlenberg et al. 2006) have shown that climate change may affect the distribution, natural regeneration and successful reforestation of Mongolian conifer forests, and that newly planted species often appear to be heavily affected by human disturbances, especially unregulated livestock grazing. According to statistics collected over the last 100 years, $40 \%$ of all Mongolian forests have been directly affected by human activities which have largely had adverse effects (Tsogtbaatar 2004). Overall, 684,000 ha of previously forested areas have not regenerated after fires, and another 159,000 ha have been converted into non-forested ecosystems.

The first reforestation trials were carried out in Mongolia in the 1970s. However, efforts at forest rehabilitation with native species have had relatively limited success around the country. Today, most plantations are monocultures established from 2-year-old seedlings of Larix sibirica Lebed. and Pinus sylvestris L. Chamshama et al.

Table 1 Description of the permanent sample plots used for this study in 2010

\begin{tabular}{|c|c|c|c|c|c|c|c|c|c|}
\hline \multirow[t]{2}{*}{ Sample plot } & \multirow{2}{*}{$\begin{array}{l}\text { Establishment } \\
\text { of } \\
\text { reforestation }\end{array}$} & \multirow{2}{*}{$\begin{array}{l}\text { Age } \\
\text { (seedling/ } \\
\text { sapling) by } \\
2010\end{array}$} & \multirow{2}{*}{$\begin{array}{l}\text { Mean } \\
\text { height in } \\
\mathrm{cm} \pm \mathrm{SD} \\
\text { in } 2010\end{array}$} & \multirow{2}{*}{$\begin{array}{l}\text { Mean } \\
\text { diameter in } \\
\mathrm{mm} \pm \mathrm{SD} \\
\text { in } 2010\end{array}$} & \multirow{2}{*}{$\begin{array}{l}\text { Basal area } \\
\text { in } \mathrm{m}^{2} / \\
\mathrm{ha}^{-1} \text { in } \\
2010\end{array}$} & \multicolumn{3}{|c|}{ Geographical location } & \multirow{2}{*}{$\begin{array}{l}\text { Previous } \\
\text { anthropogenic } \\
\text { disturbance } \\
\text { impact }\end{array}$} \\
\hline & & & & & & Latitude & Longitude & $\begin{array}{l}\text { Elevation } \\
\text { in } \mathrm{m}\end{array}$ & \\
\hline $\begin{array}{l}\text { Bayanbulag } \\
\text { (BB) }\end{array}$ & 2003 & 10 & $145 \pm 2.3$ & $45.2 \pm 0.6$ & 3.26 & 50,011 & 106,026 & 720 & $\begin{array}{l}\text { high. i. (1999); } \\
\text { clear-cut } \\
\text { (2000-2002) }\end{array}$ \\
\hline $\begin{array}{l}\text { Moilt guu } \\
\text { (MG) }\end{array}$ & 2004 & 9 & $140.4 \pm 1.7$ & $35.3 \pm 0.4$ & 2.77 & 50,010 & 106,024 & 706 & $\begin{array}{l}\text { high i. (1999); } \\
\text { clear-cut } \\
\text { (2002-2003) }\end{array}$ \\
\hline $\begin{array}{c}\text { Bayanbulagyin } \\
\text { denj (BBD) }\end{array}$ & 2005 & 8 & $112.9 \pm 1.9$ & $26.4 \pm 0.5$ & 1.34 & 50,012 & 106,028 & 698 & $\begin{array}{l}\text { med. i. (1997); } \\
\text { clear-cut } \\
(2001-2004)\end{array}$ \\
\hline $\begin{array}{l}\text { Tujyin nars } \\
\text { (TN) }\end{array}$ & 2006 & 7 & $67.9 \pm 1.5$ & $16.1 \pm 0.4$ & 0.45 & 50,012 & 106,032 & 694 & $\begin{array}{l}\text { high i. (1999 } \\
\text { and 2003); } \\
\text { clear-cut } \\
(2004)\end{array}$ \\
\hline $\begin{array}{l}\text { Khudgyin guu } \\
\text { (KHG) }\end{array}$ & 2007 & 6 & $54.6 \pm 1.4$ & $11.8 \pm 0.4$ & 0.21 & 50,009 & 106,032 & 703 & $\begin{array}{l}\text { high i. (2005); } \\
\text { clear-cut } \\
(2005-2006)\end{array}$ \\
\hline $\begin{array}{l}\text { Khudgyin } \\
\text { guunyiar } \\
\text { (KGA) }\end{array}$ & 2008 & 5 & $7.6 \pm 0.6$ & $1.5 \pm 0.1$ & 0.001 & 50,007 & 106,015 & 700 & $\begin{array}{l}\text { med i. (2005); } \\
\text { clear-cut } \\
(2006-2007)\end{array}$ \\
\hline
\end{tabular}

All plots were established on previously clear-cut and burned sites: high i = high intensity fire; med $\mathrm{i}=$ medium intensity fire; years in brackets; $\mathrm{SD}=$ standard deviation. Diameter was measured at stem base 


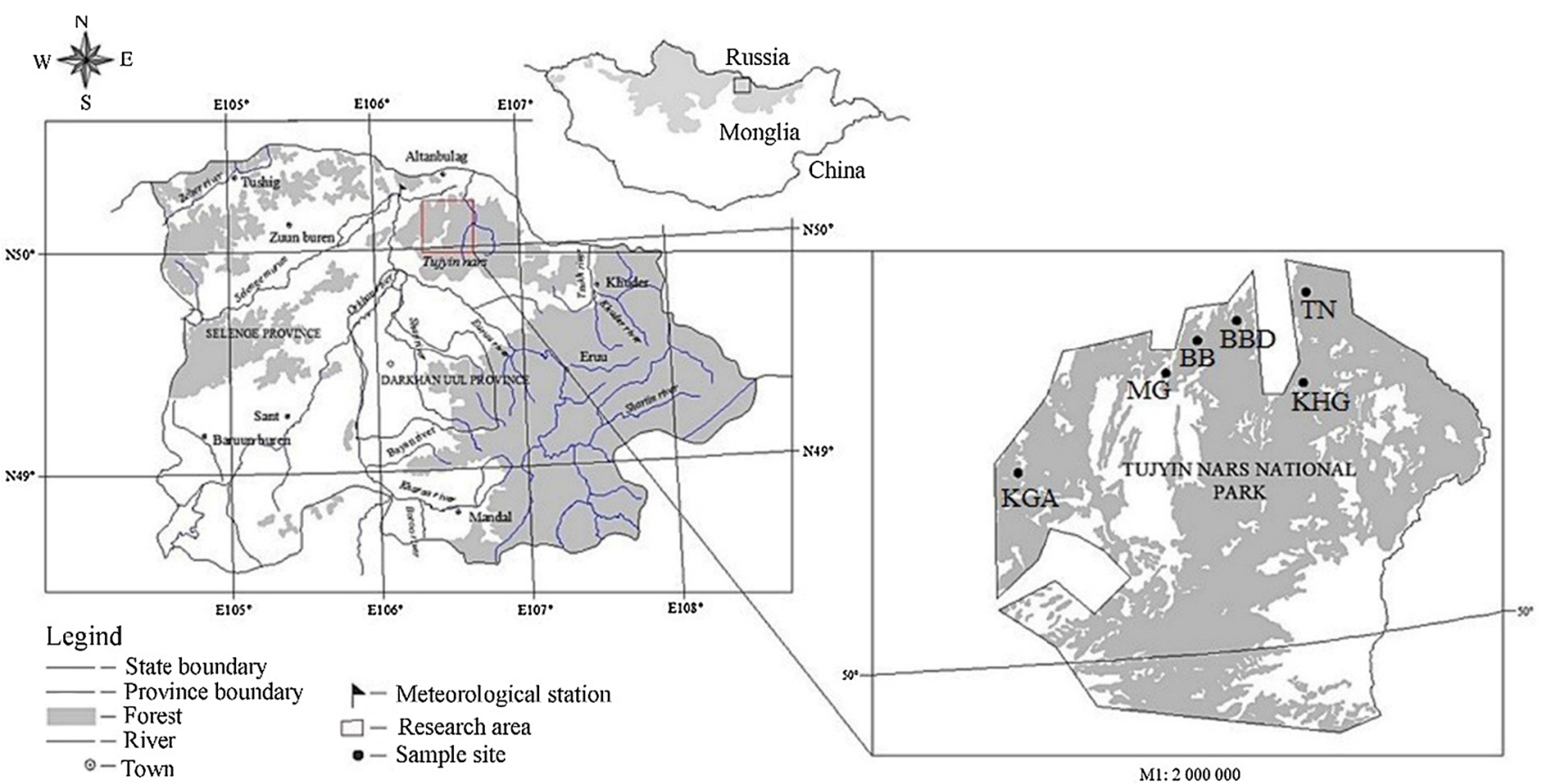

Fig. 1 Location of the study area in the Tujyin Nars National Park (Selenge province) with the six sample sites (see Table 1 for the abbreviations of the sites)

(2009) underline the degree to which successful plantation establishment depends on planting design and the selection of appropriate species but also relies on silvicultural, ecological and economic aspects. Scots pine (P. sylvestris) is an important species for the region in terms of forest cover, timber production and reforestation management. Planting of Scots pine is typically carried out in the first half of May which usually coincides with a lack of rainfall, prolonged drought and high winds. The Tujyin Nars Special Protected Area (SPA) is a representative area for successful reforestation in northern Mongolia. Current statistics show that over the last two decades, some 21,000 ha of previously logged land in the Tujyin Nars region have been artificially reforested (Gerelbaatar 2012). In spite of the importance of forest plantations in Mongolia, there is little information on early survival and growth performance of seedlings. The main objectives of this study were: (1) to assess seedling survival and growth with respect to plantation age; and, (2) to analyze the effects of climate factors on seedling survival during the growing season in the early stages of establishment. Following an in-depth analysis of the results, survival rate and growth of seedlings is explained with linear mixed-effects models (LMM).

\section{Materials and methods}

\section{Site description}

The study was carried out in the Tujyin Nars National Park $\left(50^{\circ} 05^{\prime}\right.$ and $50^{\circ} 12^{\prime} \mathrm{N}, 106^{\circ} 14^{\prime}$ and $\left.106^{\circ} 31^{\prime} \mathrm{E}\right)$ in the Selenge province of northern Mongolia (Fig. 1). The SPA stretches approximately $33 \mathrm{~km}$ from east to west and covers an area of 73,000 ha, of which 45,800 ha are natural pine forests and 21,000 ha are Scots pine plantations (Gerelbaatar 2012).

According to the updated world map of the KöppenGeiger climate classification (Peel et al. 2007), the region lies within the transition climatic zone between a cool continental climate (Dwc) and a cold semi-arid climate (Bsk), with small pockets exhibiting a temperate continental climate (Dwb). The temperature at the nearest meteorological station in Sukhbaatar, 15-20 km north-west at $660 \mathrm{~m}$ between 2003 and 2014 averaged $0.3{ }^{\circ} \mathrm{C}$. The average annual precipitation was $249.8 \mathrm{~mm}$ with a precipitation peak between June and August. The dry season extends from March to June in spring and from August to October in autumn (Regzedmaa 2008). According to meteorological data, total annual precipitation and mean annual temperatures have varied over previous decades. Figure 2 provides an overview of the climate characteristics of the area based on data from the Meteorological station Sukhbaatar, 2003-2014. 

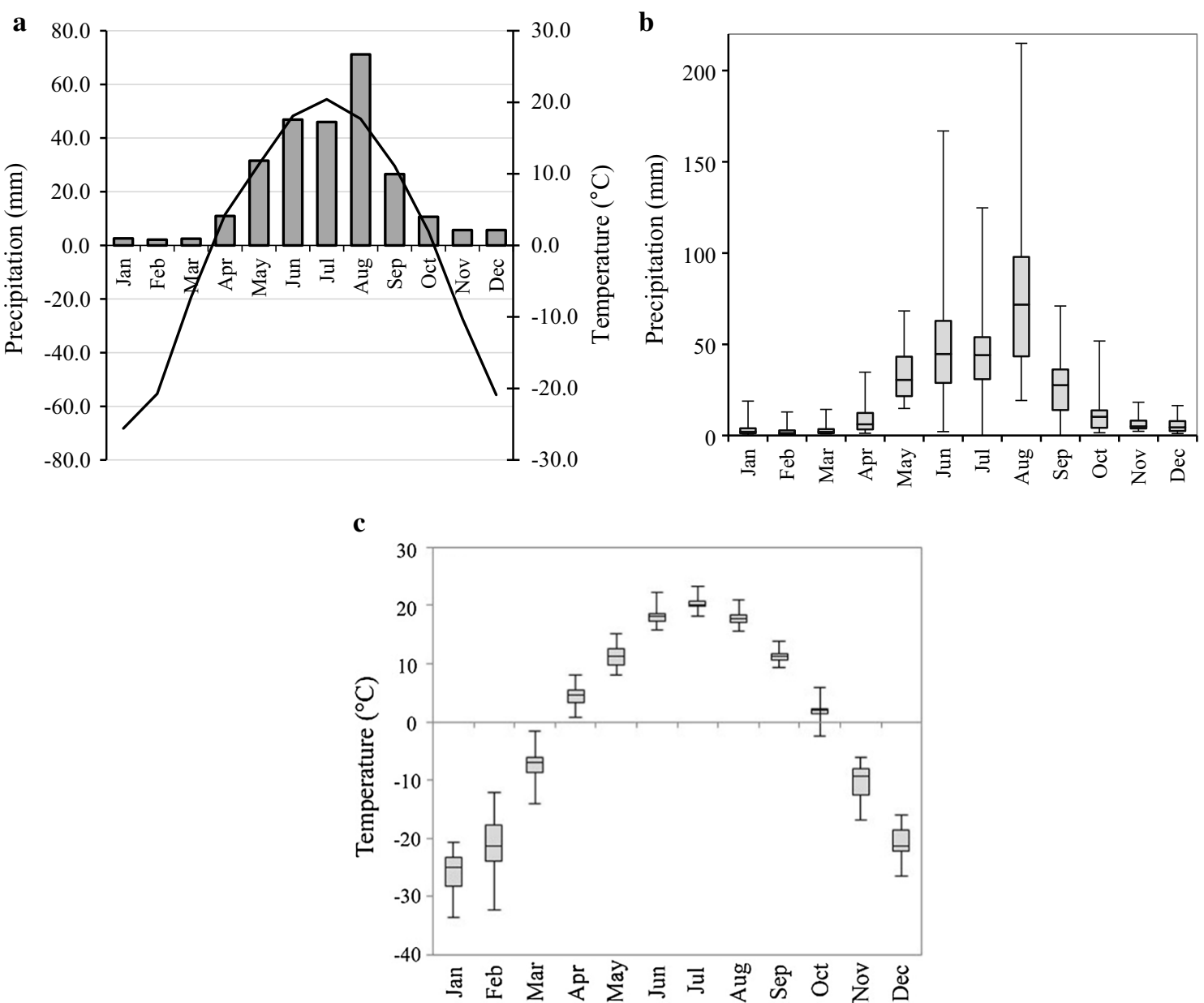

Fig. 2 Overview of the climatic conditions of the study area (meteorological station Sukhbaatar, 2003-2014). a Climate diagram; b annual precipitation; c annual temperature

The soil in the study area is mainly of haplic arenosols developed from sandy sediments (JICA 1998). Planting was carried out in the beginning of the growing season (first half of May) from 2003 to 2008. 2-year-old bare-root seedlings of Scots pine were transplanted manually using the slit planting method. The initial planting density of each plantation was 2500 seedlings ha ${ }^{-1}(4.0 \mathrm{~m} \times 1.0 \mathrm{~m}$ spacing). Six neighboring reforested stands were selected, representing early survival and growth of Scots pine. All plantations were monocultures established at different times and on clear-cut forested land following frequent intense fires (Table 1). The plantations were located close to each other and exhibited similar site conditions. They were selected to represent the typical early development phase of plantations in the study area.

\section{Measurements in the plots}

Field measurements and data collection were carried out annually in September/October between 2003 and 2010. On each of the six plantation sites five square permanent sample plots, (overall: 6 sites $\times 5$ plots $=30$ plots), each measuring $900 \mathrm{~m}^{2}(30 \mathrm{~m} \times 30 \mathrm{~m})$ in completely randomized design were established. Annual field measurements of seedlings included: diameter at stem base, total height and annual height increments. The survival rate of planted seedlings on each plot was assessed by counting both live and dead individuals at the end of the annual growing season (September). The survival rate of each plantation was estimated annually (2003-2010). Height was measured to the nearest $0.01 \mathrm{~m}$ with a measuring tape, and at stem base, the diameter was measured to the nearest $0.1 \mathrm{~cm}$ with calipers. Annual tree-ring width of medium-sized samples, ( 5 cores from each plot), were measured at the Laboratory of Dendrochronology at the Mongolian Academy of Sciences (MAS). 
Table 2 Survival of planted seedlings over the monitoring period $(\%)$

\begin{tabular}{llllllllll}
\hline Stand & Planting year & \multicolumn{7}{l}{ Year of measurements } \\
\cline { 3 - 10 } & & 2003 & 2004 & 2005 & 2006 & 2007 & 2008 & 2009 & 2010 \\
\hline BB & 2003 & 97.92 & 97.60 & 97.60 & 97.52 & 97.52 & 97.48 & 97.48 & 97.48 \\
MG & 2004 & & 92.60 & 92.40 & 92.28 & 92.28 & 92.20 & 92.20 & 92.20 \\
BBD & 2005 & & & 78.44 & 78.12 & 78.12 & 78.12 & 78.04 & 78.00 \\
TN & 2006 & & & & 61.68 & 61.52 & 61.52 & 61.40 & 61.40 \\
KHG & 2007 & & & & & 76.20 & 75.96 & 75.90 & 75.90 \\
KGA & 2008 & & & & & & 15.28 & 15.04 & 15.00 \\
\hline
\end{tabular}

$B B$ Bayanbulag, $M G$ Moilt guu, $B B D$ Bayanbulagyin denj, $T N$ Tujyin nars, $K H G$ Khudgyin guu, $K G A$ Kudgyin guunyiar

\section{Basic analyses}

\section{Anova}

For the analysis of survival and seedling growth, one-way analysis of variance (ANOVA) was used to determine statistically significant differences in means among variables between the sites, and an F-test was used to determine equality of group means (Fisher 1925; O'Brien 1979).

\section{Correlation between increment and climatic variables after plantation establishment}

Pearson's correlation coefficient (Edwards 1976) measured the strength of the linear association between the sum of annual heights and radial increments of the second and third years after plantation establishment, and the average values (annual and growing season) of climatic variables of the respective time frame: Bayanbulag (2004/2005), Moilt guu (2005/2006) Bayanbulagyin denj (2006/2007), Tujyin Nars (2007/2008), Khudgyin guu (2008/2009), Kudgyin guunyiar (2009/2010). The first year when the seedlings were planted may be considered as an adaptation phase and was therefore not included. The following climatic factors and indicators for the whole year and growing season (May-August) were considered in the correlation analyses: sum of precipitation, average air temperature, average relative air humidity and number of dry days, the latter refers to the average number of days below a critical level of air humidity $(<30 \%)$.

\section{Assessment of relative height categories}

All seedlings were classified into three height categories relevant to neighboring seedlings in each plot, which, in a similar fashion, is often applied to estimate competition in stands (see for example, Krstic et al. 2012). Since the seedlings were in a very early competition stage during which direct competition played no role or a subordinate role, the following terms were applied: 'accelerated growth' instead of 'dominant'; relatively 'average growth' instead of 'codominant'; and, 'retarded growth' instead of 'suppressed'.

\section{Comparing a negative and a positive pointer year}

Based on the results on seedling survival (Table 2), the most positive and the most negative pointer years were selected and the respective course of precipitation and temperature of the respective year compared against the average course of the climate factors during the observation period (2003-2010).

\section{Quantification of influence of dryness/humidity on survival rate and growth of planted Scots pine trees in Northern Mongolia with linear mixed models (LMM)}

Based on the descriptive and basic results, explanatory models were tested and developed for explaining survival rate in the year of plantation, and growth (height growth and radial growth) in subsequent years after establishment. A planted tree population $i$ at site $j$ represents a sample unit. A linear mixed model approach (LMM) was used to avoid pseudoreplication and include fixed effects (e.g., number of dry days during a certain period), and random effects (e.g., site or plot) (Crawley 2007; Zuur et al. 2009; R-bloggers 2011). The models were optimized based on the restricted maximum likelihood method (REML) (Zuur et al. 2009; R-bloggers 2011). We also tested for interactions between different fixed factors. Every initial model run was evaluated by a standard procedure of regression diagnostics in which outliers were detected and eliminated based on the distribution of internally studentized residuals in Q-Q plots with a 95\% confidence envelope (Robinson and Hamann 2011). The best models were selected according to the following criteria: Akaike's Information Criterion (AIC), Bayesian information criterion (BIC) and 
the value of the log likelihood, the plausibility of the intercept, the distribution of residuals, and the plausibility of the respective model from an ecological point of view (Gradel et al. 2017a). Spatial autocorrelation was accounted for within the sites in the mixed model procedure (Zuur et al. 2009). At no time was it necessary to incorporate a spatial dependence structure in the model. The average survival rate $\left(S_{i j}\right)$ in the year of plantation establishment was explained by the number of dry days in May $(D)$. The following model was selected:

$S_{i j}=\left(\beta_{0}\right) I+\left(\beta_{1, i}\right) D+\left(b_{2, j}\right) s+\varepsilon_{i j}$

where $\beta_{0}, \beta_{1, i}, b_{2, j}$ are the parameter estimates of the intercept $(I)$, the number of dry days in May $(D)$, and the site $(s)$, respectively; $\varepsilon_{i j}=$ error term of the population $i$ at site $j$.

A model was developed for the description of average growth in the subsequent years after planting. The model explained average height growth $\left(H_{i j}\right)$ and average radial growth $\left(R_{i j}\right)$ of the subsequent years after planting. The growth model of the plantation $i$ of site $j$ consisted of the following elements:

$H_{i j}=\left(\beta_{0}\right) I+\left(\beta_{1, i}\right) h+\left(b_{2, j}\right) s+\varepsilon_{i j}$

$R_{i j}=\left(\beta_{0}\right) I+\left(\beta_{1, i}\right) h+\left(b_{2, j}\right) s+\varepsilon_{i j}$

where, $\beta_{0}, \beta_{1, i}, b_{2, j}$ are the parameter estimates of the intercept $(I)$, the annual relative average air humidity $(h)$ of the plantation and the site $(s)$ respectively; $\varepsilon_{i j}=$ error term of the population $i$ at site $j$.

The following software packages/routines were used: R-statistics (R Development Core Team 2016) with the packages nls2 (Grothendieck 2013), nlme (Pinheiro et al. 2018), ncf (Bjornstad 2013), car (Fox and Weisberg 2011), and lattice (Sarkar 2008). As part of the LMM (R-bloggers 2011), the test for spatial autocorrelation was conducted

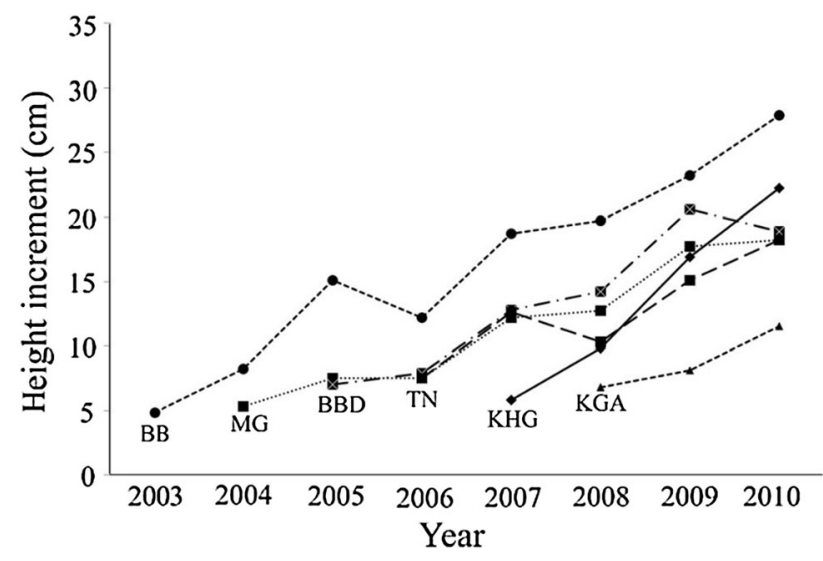

Fig. 3 Height growth of planted trees. $B B$ Bayanbulag, $M G$ Moilt guu, $B B D$ Bayanbulagyin denj, $T N$ Tujyin nars, $K H G$ Khudgyin guu, $K G A$ Kudgyin guunyiar

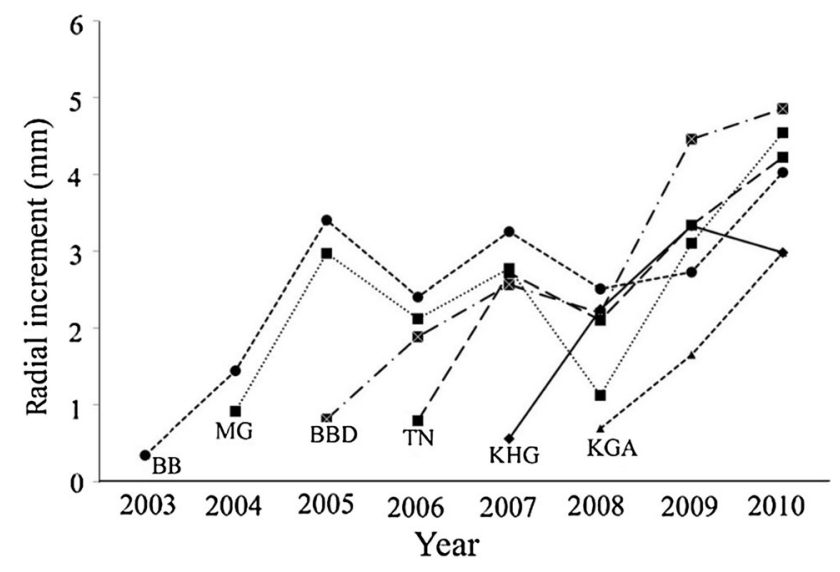

Fig. 4 Radial growth of planted trees. $B B$ Bayanbulag, $M G$ Moilt guu, $B B D$ Bayanbulagyin denj, $T N$ Tujyin nars, $K H G$ Khudgyin guu, $K G A$ Kudgyin guunyiar

with an adjusted script based on a version from Gradel et al. (2017a); an initial version was provided by the Chair of Silviculture at TU Dresden.

\section{Results}

\section{Survival rate}

\section{Survival rate over the monitoring period}

There was a massive mortality of seedlings during the growing season the first year after plantation establishment in 2006, 2007 and especially in 2008 (sites TN, KHG, and KGA). There was a significant difference $(p<0.001$, $\mathrm{F}=29.7)$ in the rate of seedling survival among the plantations. Table 2 provides an overview of the survival of planted seedlings over the monitoring period in the plantations.

\section{Survival rate and climate impact}

We first analyzed the distribution of annual monthly air temperatures and precipitation collected from the neighboring Sukhbaatar meteorological station. The variation of annual precipitation $(p<0.001, \mathrm{~F}=4.6)$ and air temperatures $(p=0.006, \mathrm{~F}=9.1)$ were significantly high, and precipitation showed an uneven distribution during growing seasons (Fig. 2). The survival of Scots pine plantations correlated positively with monthly precipitation and air temperatures during the growing season. In contrast, seedling survival was more dependent on monthly precipitation than on air temperatures. A relatively strong correlation between rainfall and seedling survival was observed in June $(\mathrm{r}=0.41 ; p=0.05)$ and July $(\mathrm{r}=0.46$; $p=0.05)$. However, among of all climatic factors and 
Table 3 Pearson's 'correlation coefficient' between the sum of increment (second and third year after planting) and respective values of climatic factors and indicators; sum of precipitation (sum_prec), average air temperature ( $\mathrm{T} \_$air), average relative air humidity $(\mathrm{H})$ and number of dry days (D)

\begin{tabular}{|c|c|c|c|c|c|c|c|c|}
\hline & $\begin{array}{l}\text { sum_prec } \\
\text { (annual) }\end{array}$ & $\begin{array}{l}\text { sum_prec } \\
\text { (vegetation } \\
\text { period) }\end{array}$ & $\begin{array}{l}\text { T_air } \\
\text { (annual) }\end{array}$ & $\begin{array}{l}\text { T_air } \\
\text { (vegetation } \\
\text { period) }\end{array}$ & $\begin{array}{l}\mathrm{H} \\
\text { (annual) }\end{array}$ & $\begin{array}{l}\mathrm{H} \\
\text { (vegetation } \\
\text { period) }\end{array}$ & $\begin{array}{l}\mathrm{D} \\
\text { (annual) }\end{array}$ & $\begin{array}{l}\mathrm{D} \\
\text { (vegetation } \\
\text { period) }\end{array}$ \\
\hline $\begin{array}{l}\text { Height increment (sum of } \\
\text { second and third year) }\end{array}$ & 0.28 & 0.13 & 0.47 & 0.11 & 0.24 & 0.27 & 0.21 & 0.17 \\
\hline $\begin{array}{l}\text { Radial increment (sum of } \\
\text { second and third year) }\end{array}$ & 0.72 & 0.59 & 0.64 & 0.10 & 0.60 & $0.73 *$ & 0.25 & 0.26 \\
\hline
\end{tabular}

*With $p \leq 0.1$

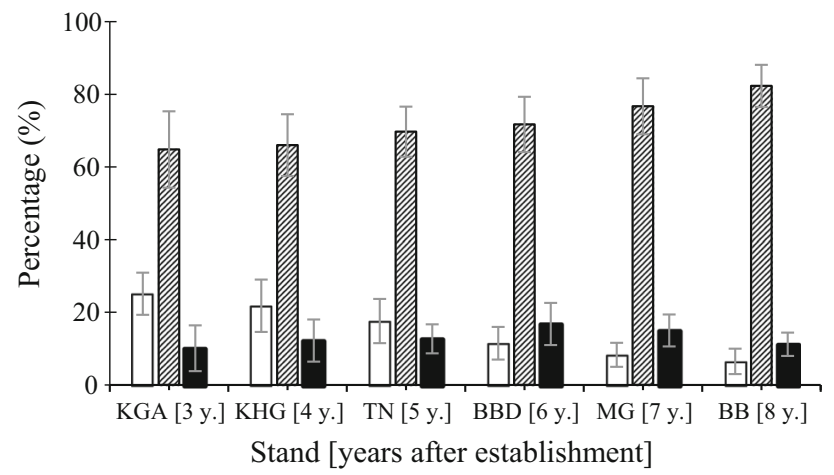

Fig. 5 Relative proportion of seedlings by height categories in relation to neighborhood composition. Growth categories: white: accelerated growth; striped: average growth; black: retarded growth. $B B$ Bayanbulag, $M G$ Moilt guu, BBD Bayanbulagyin denj, $T N$ Tujyin nars, $K H G$ Khudgyin guu, $K G A$ Kudgyin guunyiar

indicators, the number of dry days $(D)$ showed the strongest correlation with seedling survival: $\left(D_{\text {may }}\right.$ : $0.76, D_{\text {june }}$ : $0.69, \mathrm{D}_{\text {vegetation period }}$ : 0.71 with $p=0.005$ and $\mathrm{F}=3.76$ ).

\section{Growth performance over the monitoring period}

Height and radial increments in the first year following transplanting were consistently less than those measured in the second year, and ranged from $4.8 \pm 1.2$ to $7.5 \pm 1.6 \mathrm{~mm}$ in height and $0.3 \pm 0.2$ to $0.9 \pm 0.2 \mathrm{~mm}$ in radial growth, and clearly dependent on the amount of rainfall in the growing season. These results reveal that annual height increments of seedlings for the plantations exhibited similar growth trends that increased in the second year after planting, effectively in parallel with the age of the plantation (Figs. 3, 4).

While growth trends among the plantations were similar, a significant difference in height growth was observed ( $p=0.0004 ; \mathrm{F}=26.8$ ). The mean annual height increment of seedlings differed for all plantations, of which the lowest was observed in BB and highest in BBD (Fig. 3).
When assessing radial growth, there was a similar tendency as in height growth; the annual increment of radial growth in the planting year was the lowest, which may in part be related to transplant shock (Figs. 3, 4). For all plantations, a gradual increase of both height and radial increment was observed at the beginning of the second year. Increasing height and radial increment of seedlings/ saplings was recorded each year, with the exception of 2006 and 2008, with particular focus to radial growth. The standard deviation of individual tree height growth was often higher than for radial growth measured in each plantation.

\section{Growth performance and climate impact after plantation establishment}

The initial analysis of the impact of climate variables on height and radial growth in the second and third years after planting indicated rather low values for height growth. With regard to effects on radial growth, precipitation, air humidity and temperature showed higher correlation values, but only the relation between radial growth and average annual relative air humidity, showed a significant correlation (Table 3).

\section{Distribution of planted trees by height categories}

All seedlings were divided into three height growth categories: accelerated growth, average growth and retarded growth. Overall, the distribution of trees by height categories did not significantly differ $(p=0.18 ; \mathrm{F}=2.62)$ among plantations with different ages. In this study, most of the planted trees belonged to the average growth category $(64-81.6 \%)$, while $15.0 \pm 3.2 \%$ of the remaining trees were classified as accelerated growth and $11.8 \pm 1.3 \%$ were in the retarded growth category (Fig. 5). The greatest variation in height categories were observed at the time of plantation establishment. 

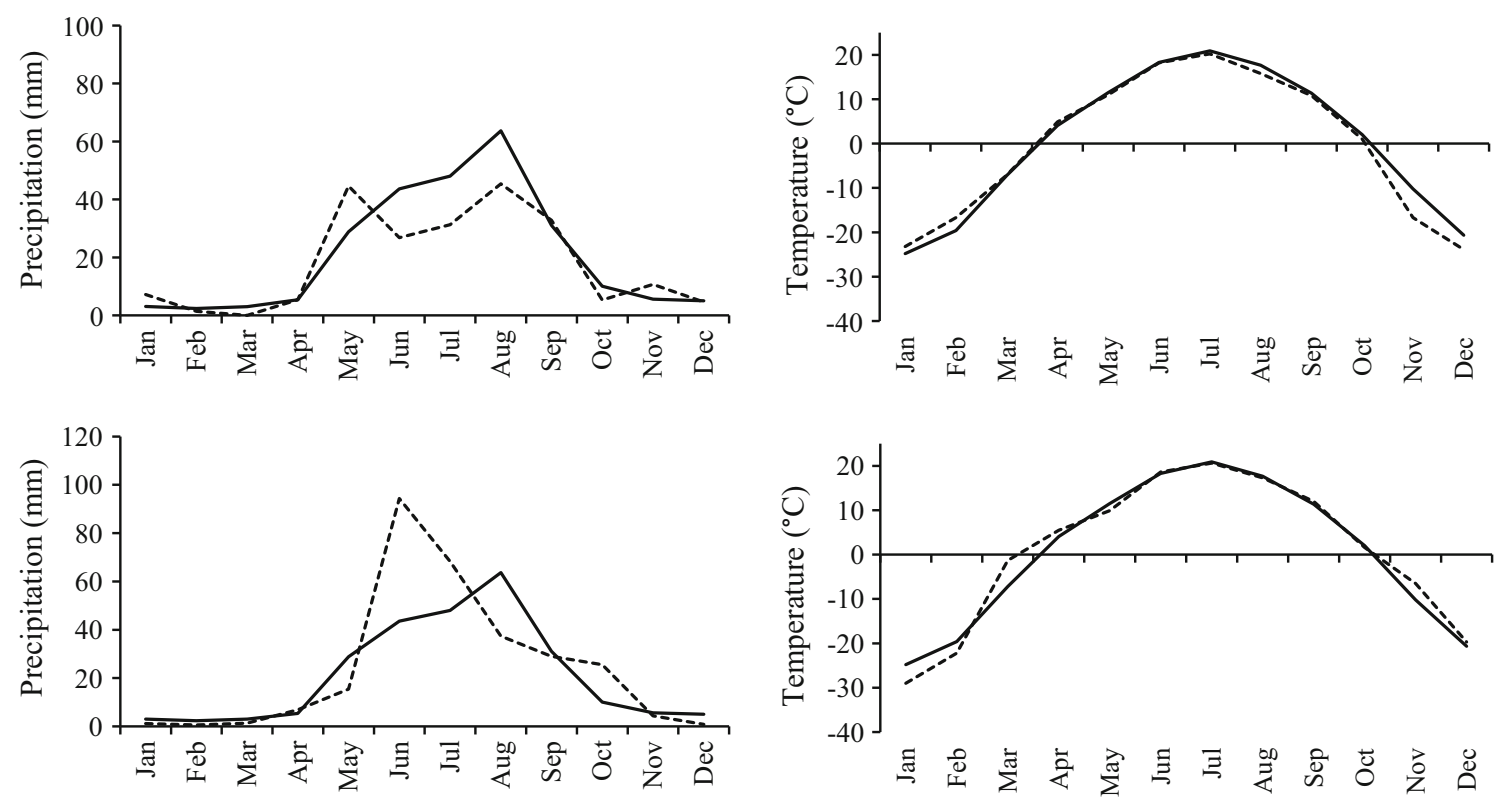

Fig. 6 Average course of precipitation and temperature during the period 2003-2010 shown as solid line. Actual course of precipitation shown as dashed line. Data from meteorological station Sukhbaatar

Table 4 Overview of the linear mixed effect models for survival rate in the planting year (2003-2008 respectively) and growth in the following years (2004-2010); only models with a level of significance of the fixed effect value with $p<0.05$ are shown

\begin{tabular}{|c|c|c|c|c|c|c|c|c|}
\hline \multirow[t]{2}{*}{ Model } & \multirow[t]{2}{*}{ Variable } & \multirow[t]{2}{*}{ Fixed effects } & \multirow[t]{2}{*}{ Degrees of freedom } & \multicolumn{4}{|c|}{ Model parameter (fixed effects) } & \multirow[t]{2}{*}{ AIC of the model } \\
\hline & & & & Intercept & $p$ value & Fixed effect & $p$ value & \\
\hline 1. Survival_rate & Survival & $\mathrm{D}_{\text {may }}$ & 4 & 106.610 & 0.001 & -2.559 & 0.034 & 50.386 \\
\hline \multirow[t]{2}{*}{ 2. Growth } & Height growth & $\mathrm{H}$ & 20 & -41.179 & 0.000 & 0.759 & 0.000 & 149.620 \\
\hline & Radial growth & $\mathrm{H}$ & 17 & -3.645 & 0.026 & 0.092 & 0.001 & 39.920 \\
\hline
\end{tabular}

$\mathrm{D}_{\text {may }}=$ number of dry days (days with critical low value of the average relative air humidity [below 30\%] in May); $\mathrm{H}=$ average annual air humidity $(\%)$; AIC = Akaike's Information Criterion. The minimum number of dry days was $\mathrm{D}_{\text {may }}=5$

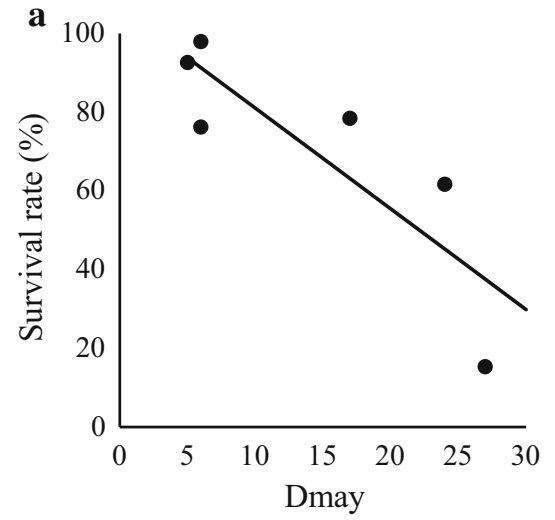

Fig. 7 LMM - graphics: relationship between the number of dry days $\left(D_{\text {may }}=\right.$ days with critical low value of the average relative air humidity [below 30\%] in May) and the survival rate of the planted
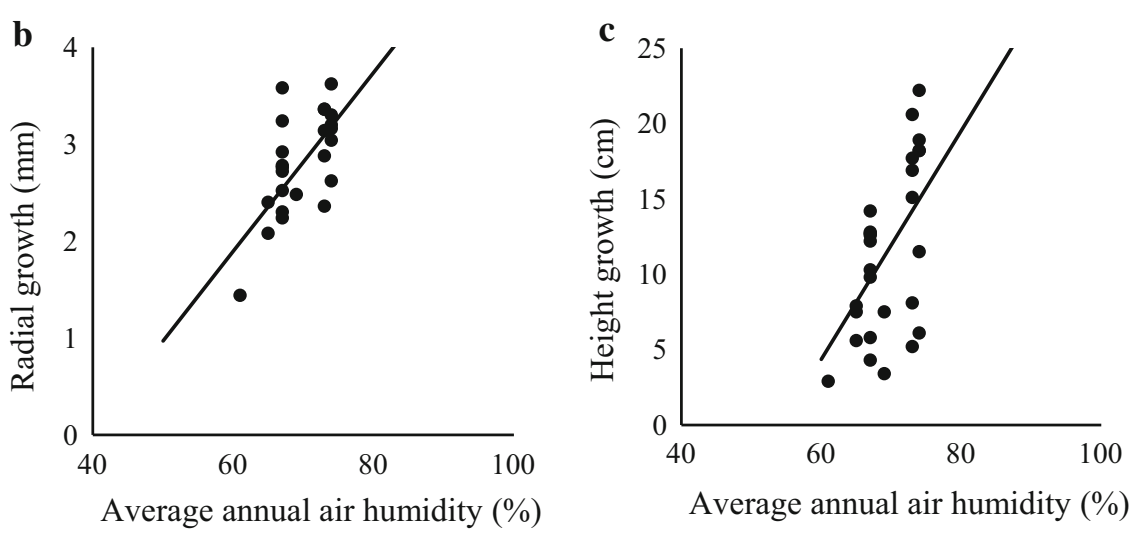

Scots pine trees (a). Relationship between the average annual relative air humidity and radial growth (b) or height growth (c), respectively 


\section{Comparative diagrams of the most positive and most negative pointer years related to planting success}

In terms of seedling survival in the year of planting, 2003 was identified as a positive pointer year (survival rate $>$ 97\%) and 2008 as negative pointer year (survival rate $<16 \%$ ), as shown in Table 2 . The annual sum of precipitation of the positive pointer year (2003) was below average but above average during May. Conversely, in the negative pointer year (2008), the precipitation in May was below average, whereas the sum of precipitation was relatively high (Fig. 6).

\section{Modeling of the influence of dryness and humidity on the survival rate and growth of planted Scots pine}

Based on the results, linear mixed models were developed to predict first-year survival and growth rates over subsequent years. Sufficient humidity levels significantly influenced survival rates of planted pine seedlings in the first year and strongly contributed to seedling growth in subsequent years. Different indicators, however, provided the best results for predicting survival and growth rates.

The number of dry days in late spring $\left(D_{\text {may }}\right)$ had a particularly strong impact on first-year survival and varied considerably from year to year. With regard to seedling growth after plantation establishment (second year onwards), average annual relative air humidity $(H)$ provided the most reliable results for the whole observation period. Both explanatory approaches (height growth and radial growth) resulted in highly significant $p$ values for the explanatory variable. The variation of $H$ was relatively low throughout all the study years; see Table 4, Fig. 7 for a graphical representation of the models.

\section{Discussion}

\section{Climate factors determine plantation success}

In this study, seedling survival and growth in the forest steppe of northern Mongolia are largely dependent on climatic factors. As expected, the amount of precipitation and its distribution throughout the growing season is crucial. The study region is characterized by highly variable rainfall regimes and relatively low air humidity levels throughout the growing season.

\section{Survival rate is related to meteorological conditions}

First-year survival of transplanted seedlings plays a crucial role in the subsequent success of plantations. Brunner et al. (2015) noted that seedlings might take some time after planting to re-establish appropriate root architecture systems able to support the growth of apical shoots. Thus, the first months after planting are a decisive time for planting success. Sufficient water supplies during the initial growing season, especially immediately after planting, is a major determining factor for reforestation success. Our data analyses indicated that a lack of humidity during and directly after initial planting causes mass mortality of seedlings (Table 2; Fig. 6). On the other hand, sufficiently humid conditions during the month of May allowed for fairly good survival. This became especially clear through the comparative diagrams of the pointer years and the survival model of seedlings. Mass mortality was observed in 2008 (KGA) (Table 2), which may be explained by a lack of rainfall for May. Interestingly, instead of precipitation itself, it was the number of dry days in May, which we consider as a kind of dryness indicator, which gave the best model results for seedling survival (Fig. 7a). Critical dry periods in June $2006(2.5 \mathrm{~mm})$ and May 2008 $(15.4 \mathrm{~mm})$ resulted in relatively low survival of first-year seedlings in plantations TN (61.7\%) and KGA (15.3\%), respectively (Table 2). Meanwhile, in 2003, 2004 and 2007 , the amount of rainfall during the growing season was relatively high and resulted in better survival rates, as recorded in BB (97.9\%), MG (92.6\%) and BBD (78.4\%) (Table 2). These observations indicate that weather conditions during spring, specifically the month of May (versus the sum of precipitation measured for the whole year), played a crucial role for seedling survival in this region of Mongolia. This study provides a quantitative orientation for projected survival rates based on the number of dry days $(D)$ in May (Fig. 7a). One of the reasons why weather conditions in May were important in the analysis of seedling survival was that the seedlings were planted during May. Establishing plantations in autumn may lead to different results, in terms of both individual tree survival and fixed-effects on forest structural parameters. The results, however, show that environmental conditions, both during and immediately after planting, represent a key factor in the successful survival of seedlings in Mongolia.

\section{Growth performance of Scots pine}

Regarding growth performance after plantation establishment, the pattern is somewhat different. Water availability throughout the year is of much greater importance. The correlation of height and radial growth with total annual precipitation was higher than for the growing season (Table 3). The LMM results for height and radial growth modeling showed that growth of the plantations can be directly related to air humidity throughout the year (Fig. 7b). Air humidity may be considered as an indicator of planting success, which incorporates both precipitation 
and temperature. In general, seedlings are typically more sensitive to water deficits than older trees due to their less developed root systems. For example, a climate-growth study in the Altansumber research area of the Mongolian mountain forest steppe showed that young birch trees were more prone to react favorably to precipitation than older trees (Gradel et al. 2017b). However, these findings were observed in naturally regenerated forests. Scots pine is a light-demanding species that is moderately drought resistant and has modest nutritional requirements which makes it better suited to nutrient poor soils than other species (Lawson and Michler 2014). The absence of shading from mature trees in stands might have had a favorable effect on seedling growth during the early stages of plantation establishment. The largest differences between relative height categories were observed in the first two years after planting, which was mainly caused by individual adaptation to the new growing environment. The ever-increasing proportion of average classified height categories and gradual reduction of accelerated height categories indicates a low competition rate between individuals. Our results show that during the first years of plantation establishment, variations in height among individual seedlings gradually decreased (Fig. 5). This will most likely change as the trees grow older and competition becomes more important. Competition is another important factor affecting tree growth (Gadow 2005; Gadow et al. 2012; Klädtke et al. 2012; Gradel et al. 2017a). In the context of the current developmental stage of the Scots pine plantations, drought stress is the dominant limiting factor for seedling survival (Dulamsuren et al. 2013) and growth (Cregg and Zhang 2001; Turtola et al. 2003). It has also been shown that for mature Scots pine, a clear correlation exists between growth and water availability in the forest steppe zone (Babushkina and Belokopytova 2014; Demina et al. 2017). Water availability is considered the most important limiting factor affecting plant productivity and is an important ecosystem driver in general (Heisler-White et al. 2008; Liu et al. 2013). Williams et al. (2013) highlighted the finding that semi-arid forests experience seasonal water stress and may be particularly vulnerable to even slight increases in water deficit, which can inhibit tree growth and trigger increased mortality. A study on tree distribution, growth and survival within populations of Scots pine grown at sites in Europe and North America showed that even modest climate warming will likely have a positive influence on Scots pine survival and growth in the northern parts of the species range, and will negatively impact the more southern range of the species (Reich and Oleksyn 2008).

\section{Forest plantations in the context of climate change in Mongolia}

Temperatures in the southern boreal forests of Eurasia have warmed rapidly in recent decades, particularly in spring, and this is projected to continue in coming decades (Schär et al. 2004; IPCC 2007). A number of studies have reported that global warming, combined with increasing aridity, are the main drivers of changes in species composition (Pawson et al. 2013; Benavides et al. 2015), and directly impact on forest ecosystem rehabilitation (Hattori et al. 2013). Consequently, forest vulnerability to climate change has increasingly becomes a topic of considerable interest to the forestry sector, most notably in Eastern Asia (FAO 2010; Cui et al. 2016). Recent studies have shown that semi-arid ecosystems are particularly vulnerable to climate change and the increased risk of more frequent and severe droughts (Ma et al. 2015; Rammig and Mahecha 2015). A recent study indicated that the physiological responses of seedlings to drought stress that ultimately causes them to die, can differ between species (Ivanov et al. 2019). Findings from this study identified carbon starvation, resulting from rapid root growth at the onset of water stress, as the primary cause of death for Scots pine seedlings. To date, relatively few studies have addressed the effects of climate warming on seedling mortality and growth of forest plantations in Mongolia (Dulamsuren et al. 2013). Forests have the potential to buffer climate effects, notably by protecting the soil from high solar radiation and elevated summer temperatures. In the context of global warming, effective climate resilient afforestation and reforestation efforts have become critically important for the future of Mongolia. The combined effects of accelerating climate change, ongoing desertification, and the ever-present risk of drought projected to occur with higher frequency (Oyuntuya et al. 2015; Ubugunov et al. 2017), underline the need to develop sustainable and effective forest planting practices to respond to the unique set of conditions specific to Mongolia. Lower survival rates and largely ineffective reforestation efforts have limited forest plantations in Mongolia to only 300,000 ha. Approximately $30 \%$ of these have been established in the Selenge Aimag. Valuable insight can be gained from similar scenarios in other Asian countries, for example, by using containerized seedlings instead of bareroot seedlings. One option might be to incorporate the use of mycorrhiza or endophytic fungi to enhance plant growth. Mycorrhizal fungi are known to improve plant ability to absorb both nutrients and water as they effectively increase the surface area of absorbing roots and, in general, lead to improved plant health and biomass production (Dighton and Skeffington 1987; Niemi et al. 2002; Alberton et al. 2010). For greater success in establishing plantations in harsh environments under dry soil conditions, Cortina et al. 
(2013) suggested planting seedlings previously cultivated in the open air and under nutrient-limited conditions favorable for root development. An evaluation by Cao et al. (2011) concluded that four key factors should systematically be considered during the early stages of afforestation projects: climate, pedology, hydrology and landscape characteristics. In certain cases, integrating protective coverage of native herb-layer vegetation is appropriate for generating revenue for the local communities (e.g., medical herbs) (Jiang et al. 2016). With regard to species adaptability to new environments with drier conditions, several studies have proposed provenance tests of different regional Scots pine (e.g., Gülcü and Bilir 2017).

\section{Ecosystem-based adaptation and climate-smart forestry in Mongolia}

A targeted approach, such as climate-smart forestry, to build resilient forests in the mountain steppes may allow for a mixture of two or three species, including broadleaved pioneer species (e.g., birch or aspen). In reforestation efforts with mixed plantations, preference should be given to native species and, where possible (depending on specific site conditions and seedling availability), to more than one native species. Reforestation with multiple native species may help to ensure plantation success. In more forested regions (e.g., Khentii Mountains), enrichment planting might be considered as a means of protecting existing stands and associated ecosystem services by further adding more valuable species, e.g. Siberian larch (L. sibirica Ledeb.) or Siberian stone pine (Pinus sibirica Du Tour). Wang et al. (2012) recommended that forests should be planted with an optimal structure and spatial distribution adapted to the water-carrying capacity of local soils and groundwater conditions. It may therefore also be interesting to research the effect of different planting schemes, such as planting in groups and troops, on survival rate and growth. For example, a comparative study of different planting schemes for oak (Quercus spp.) in Germany, Austria and Switzerland found that troop planting resulted in better stem shape. Troop sizes with more than twelve individuals showed higher survival rates than planting in rows (Saha et al. 2013). There is also an indication that, for different reasons, clumped tree distribution, (potential effects of environmental disturbance and microclimatic conditions), is a common and, in part, natural feature of forest types in the Mongolian mountain forest steppes (e.g., larch and birch forests) (Gradel et al. 2015, 2017b). Landscape features should be considered, e.g., on drier slopes to concentrate planting on the lower parts between humps and small valleys and avoid planting on dry humps.

\section{Conclusions}

The Tujyin Nars region is a representative site of successful tree planting in Mongolia, and provides ample opportunity to derive general conclusions and recommendations for future planting programs. Our study showed high survival for Scots pine after the first growing season. Observations of steadily increasing height and radial increments, combined with a gradual reduction of growth variations, indicate considerable potential for plantation establishment with this well-adapted native species. Survival of Scots pine seedlings are directly related to meteorological conditions in May (see Fig. 7a). This planting period, however, coincides with unfavorable environmental conditions such as prolonged drought and frequent windstorms, both which effectively create conditions for mass loss of seedlings. This study provides threshold limits for dry days in May that relate to plantation success. As climatic factors and time of planting have a major effect on plantation success, it is critical to rethink current planting practices and research alternatives. Growth performance during subsequent years was best explained by relative air humidity levels throughout the entire growing season (Fig. 7b), which may be considered as an indicator of general water availability. Climate-resilient reforestation guidelines should be developed for different regions throughout Mongolia. Historical data on previous forest cover, soil characteristics, planting schemes, and optimal planting seasons should be considered. If the site was previously forested, species selection should focus on the natural dominant species.

Acknowledgements The authors would like to acknowledge colleagues at the Tujyin Nars SPA Administration for providing human resources necessary for field data collection. Our sincere thanks to Matthias Meyer (TU Dresden) for valuable comments and to Aimee Orsini (Berkeley, California) for the careful language editing of our manuscript. We are thankful for the useful comments and recommendations of two anonymous reviewers. The R-script for the test for spatial autocorrelation is based on an earlier version from the Chair of Silviculture at TU Dresden (see Gradel et al. 2017a). Results of this study were presented at the GMIT Symposium on Environmental Science and Engineering held in Ulaanbaatar, Mongolia in August, 2018 (Gerelbaatar et al. 2018).

Open Access This article is distributed under the terms of the Creative Commons Attribution 4.0 International License (http://crea tivecommons.org/licenses/by/4.0/), which permits unrestricted use, distribution, and reproduction in any medium, provided you give appropriate credit to the original author(s) and the source, provide a link to the Creative Commons license, and indicate if changes were made. 


\section{References}

Alberton O, Kuyper TW, Summerbell RC (2010) Dark septate root endophytic fungi increase growth of Scots pine seedlings under elevated $\mathrm{CO}_{2}$ through enhanced nitrogen use efficiency. Plant Soil 328(1-2):459-470

Babushkina EA, Belokopytova LV (2014) Climatic signal in radial increment of conifers in forest-steppe of southern Sibiria and its dependence on local growing conditions. Russ $\mathrm{J}$ Ecol 45(5):325-332

Battles JJ, Robards T, Das A, Waring K, Keith Gilles J, Biging G, Schurr F (2008) Climate change impact on forest growth and tree mortality: a data-driven modeling study in the mixed conifer forest of the Sierra Nevada, California. Clim Change 87(1):193-213

Benavides R, Escudero A, Coll L, Ferrandis P, Gouriveau F, Hodar JA, Ogaya R, Rabasa SG, Granda E, Santamaria BP, MartinezVilalta J, Zamaro R, Espelta JM, Penueles J, Valladares F (2015) Survival vs. growth trade-off in early recruitment challenges global warming impacts on Mediterranean mountain trees. Perspect Plant Ecol Evol Syst 17(5):369-378

Bjornstad ON (2013) NCF: spatial nonparametric covariance functions. R Package Version 1.1-5. http://CRAN.R-project.org/ package $=$ ncf. Accessed 29 May 2016

Brunner I, Herzog C, Dawes MA, Arend M, Sperisen C (2015) How tree roots respond to drought. Front Plant Sci 6:1-16

Buendia C, Bussi G, Tuset J, Vericat D, Sabater S, Palau A, Batalla RJ (2015) Effects of afforestation on runoff and sediment load in an upland Mediterranean catchment. Sci Total Environ 540(1):144-157

Cao SX, Chen L, Shankman D, Wang CM, Wang XB, Zhang $\mathrm{H}$ (2011) Excessive reliance on afforestation in China's arid and semi-arid regions: lessons in ecological restoration. Earth Sci Rev 104:240-245

Chamshama SAO, Nwonwu FOC, Lundgren B, Kowero GS (2009) Plantation forestry in Sub Saharan Africa: silvicultural, ecological and economic aspects. Discov Innov 21:42-49

Chen YQ, Liu ZF, Rao XQ, Wang XL, Liang CF, Lin YB, Zhou LX, Cai XA, Fu SL (2015) Carbon storage and allocation pattern in plant biomass among different forest plantation stands in Guangdong, China. Forests 6:794-808. https://doi.org/10.3390/ f6030794

Cortina J, Vilagrosa A, Trubat R (2013) The role of nutrients for improving seedling quality in drylands. New For 44:719-732

Crawley MJ (2007) The R-book. Wiley, New York, p 942

Cregg BM, Zhang JW (2001) Physiology and morphology of Pinus sylvestris seedlings from diverse sources under cyclic drought stress. For Ecol Manag 154(1/2):131-139. https://doi.org/10. 1016/S0378-1127(00)00626-5

Crisp N, Dick J, Mullins M (2004) Mongolia forestry sector review (English, Mongolian). World Bank, Washington, p 146. http:// documents.worldbank.org/curated/en/805041468773956869/ Mongolia-forestry-sector-review. Accessed 20 Nov 2016

Cui GS, Kwak H, Choi S, Kim M, Lim CH, Lee WK, Kim JS, Chae Y (2016) Assessing vulnerability of forests to climate change in South Korea. J For Res 27(3):489-503. https://doi.org/10.1007/ s11676-015-0201-2

Demina AV, Belokopytova LV, Andreev SG, Kostyakova TV, Babushkina EA (2017) Radial increment dynamics of Scots pine (Pinus sylvestris L.) as an indicator of hydrothermal regime of the Western Transbaikalia forest steppe. Contemp Probl Ecol 10(5):476-487. https://link.springer.com/article/10.1134\% 2FS1995425517050031. Accessed 24 March 2018

Dighton J, Skeffington RA (1987) Effects of artificial acid precipitation on the mycorrhizas of Scots pine seedlings. New Phytol
107(1):191-202. https://doi.org/10.1111/j.1469-8137.1987. tb04893.x

Dulamsuren Ch, Hauk M, Leuschner C (2013) Seedling emergence and establishment of Pinus sylvestris in the Mongolian foreststeppe ecotone. Plant Ecol 214(1):139-152. https://doi.org/10. $1007 / \mathrm{s} 11258-012-0152-\mathrm{z}$

Edwards AL (1976) The correlation coefficient. An introduction to Linear regression and Correlation. W. H. Freeman, San Francisco, pp 33-46

Eycott AE, Watkinson AR, Dolman PM (2006) Ecological patterns of plant diversity in a plantation forest managed by clearfelling. J Appl Ecol 43(6):1160-1171

FAO (2010) Forests and climate change in the Asia-Pacific region. Forest and Climate Change Working Paper 7, Food and Agriculture Organization of the United Nations, Rome, Italy, p 126

Fisher RA (1925) Statistical methods for research workers. Oliver and Boyd (Edinburgh), p 336. http://www.haghish.com/resources/ materials/Statistical_Methods_for_Research_Workers.pdf. Accessed 20 Nov 2016

Fox J, Weisberg S (2011) An R companion to applied regression, 2nd edn. Sage, Thousand Oaks. http://socserv.socsci.mcmaster.ca/ jfox/Books/Companion. Accessed 15 Sept 2017

Gadow KV (2005) Forsteinrichtung. Analyse und Entwurf der Waldentwicklung. Universitätsverlag Göttingen, Reihe Universitätsdrucke, Göttingen, p 342

Gadow KV, Zhang CY, Wehenkel C, Pommerening A, Corral-Rivas J, Korol M, Myklush S, Hui GY, Kiviste A, Zhao XH (2012) Forest structure and diversity. In: Pukkula T, Gadow KV (eds) Continuous cover forestry. Managing forest ecosystems. Springer, Dordrecht, pp 29-83

Gerelbaatar S (2012) Specifics of the formation of Scots pine (Pinus sylvestris L.) plantations. Ph.D. Thesis, National University of Mongolia, Ulaanbaatar, NUM Press, Ulaanbaatar, p 117 (in Mongolian)

Gerelbaatar S, Batsaikhan G, Tsogtbaatar J, Battulga P, Batarbileg N, Gradel A (2018) Early survival and growth of planted Scots pine (Pinus sylvestris L.) seedlings in northern Mongolia. In: Vossen P, Karthe D, Gunsmaa B, Enkhjargal S (eds) Book of abstractsGMIT symposium on environmental science and engineering, Nalaikh, pp 8-9. http://gmit.edu.mn/site/files/downloads/gmit_ sese-2018_book-of-abstracts.pdf. Accessed 06 Dec 2018

Gradel A, Ochirragchaa N, Altaev AA, Voinkov AA, Enkhtuya B (2015) Spatial distribution of trees on light taiga plots before selective thinning. Mong J Agric Sci 15(2):91-99

Gradel A, Ammer C, Batsaikhan G, Ochirragchaa N, Batdorj D, Wagner S (2017a) On the effect of thinning on tree growth and stand structure of white birch (Betula platyphylla Sukaczev) and Siberian larch (Larix sibirica Ledeb.) in Mongolia. Forests 8(4): 105. https://doi.org/10.3390/f8040105

Gradel A, Haensch C, Ganbaatar B, Batdorj D, Ochirragchaa N, Günther B (2017b) Response of white birch (Betula platyphylla Sukaczev) to temperature and precipitation in the mountain forest steppe and taiga of northern Mongolia. Dendrochronologia 4:24-33. https://doi.org/10.1016/j.dendro.2016.03.005

Grothendieck G (2013) nls2: Non-linear regression with brute force. $\mathrm{R}$ Package Version 0.2. http://CRAN.R-project.org/package $=$ nls2. Accessed 28 Nov 2017

Gülcü S, Bilir N (2017) Growth and survival variation among Scots pine (Pinus sylvestris $\quad$ L.) provenances. Int $\mathrm{J}$ Genom 2017:1904623. https://doi.org/10.1155/2017/1904623

Hattori D, Kenzo T, Kendawang JJ, Irino KO, Tanaka S, Ichie T, Ninomiya I, Sakurai K (2009) Effect of light intensity and soil physic-chemical properties on seedling mortality and growth of six dipterocarp species planted for rehabilitation of degraded grassland, secondary forest and logged forests in Sarawak. 
Malaysia. Jpn J For Environ 51(2):105-115. https://doi.org/10. 18922/jjfe.51.2_105

Hattori D, Kenzo T, Kendawang JJ, Irino K, Tanaka S, Tomoaki I, Ninomiya I, Sakurai K (2013) Effect of environmental factors on growth and mortality of Parashoreea macrophylla (Dipterocarpaceae) planted on slopes and valleys in a degraded tropical secondary forest in Sarawak, Malaysia. Soil Sci Plant Nutr 59:218-228. https://doi.org/10.1080/00380768.2012.762895

Hector A, Bagchi R (2007) Biodiversity and ecosystem multifunctionality. Nature 448:188-190

Heisler-White JL, Knapp AK, Kelly EF (2008) Increasing precipitation event size increases aboveground net primary productivity in a semi-arid grassland. Oecologia 158(1):129-140

IPCC (2007) Climate change 2007: The physical science basis. IPCC Fourth Assessment Report. Contribution of working group I to the Fourth Assessment Report of the intergovernmental panel on climate change. IPCC, Geneva. Switzerland. Cambridge University Press, Cambridge, p 996

Ivanov YV, Kartashov AV, Zlobin IE, Sarvin B, Stavrianidi AN, Kuznetsov VV (2019) Water deficit-dependent changes in nonstructural carbohydrate profiles, growth and mortality of pine and spruce seedlings in hydroculture. Environ Exp Bot 157:151-160. https://doi.org/10.1016/j.envexpbot.2018.10.016

Jiang WY, Yang SL, Yang XX, Gu N (2016) Negative impacts of afforestation and economic forestry on the Chinese Loess Plateau and proposed solutions. Quatern Int 399:165-173

JICA (1998) The forest resources management study in Selenge province. Final report. Asia Air Survey Co., Ltd, Tokyo, p 116

Kahle P, Baum C, Boelcke B (2005) Effect of afforestation on soil properties and mycorrhizal formation. Pedosphere 15(6):754-760

Klädtke J, Kohnle U, Kublin E, Ehring A, Pretzsch H, Uhl E, Spellmann H, Weller A (2012) Wachstum und wertleistung der douglasie in Abhängigkeit von der Standraumgestaltung. Schweiz Z Forstwes 163:96-104 (in German)

Kongsager R, Napier J, Mertz O (2013) The carbon sequestration potential of tree crop plantations. Mitig Adapt Strat Glob Change 18:1197-1213

Krstic M, Stavretovic N, Isajev V, Bjelanovic I (2012) Crown structure of Picea omorika trees in the plantation. Arch Biol Sci 64(2):605-611

Kunstler G, Curt T, Bouchaud M, Lepart J (2005) Growth, mortality and morphological response of European beech and downy oak along a light gradient in sub-Mediterranean forest. Can J For Res 35(7):1657-1668

Lawson SS, Michler CH (2014) Afforestation, restoration and regeneration-not all trees are created equal. J For Res 25(1):3-20

Liu HY, Williams AP, Allen CD, Guo DL, Wu XC, Anenkhonov OA, Liang EY, Sandanov DV, Yin Y, Qi ZH, Badmaeva NK (2013) Rapid warming accelerates tree growth decline in semi-arid forests of Inner Asia. Glob Change Biol 19(8):2500-2510

Löf M, Karlsson M, Sonesson K, Welander T (2007) Growth and mortality in underplanted tree seedlings in response to variations in canopy closure of Norway spruce stands. Forestry 80(4):371-383

Ma XQ, Heal KV, Liu AQ, Jarvis PG (2007) Nutrient cycling and distribution in different-aged plantations of Chinese fir in southern China. For Ecol Manag 243:61-74

Ma XL, Huete A, Moran S, Ponce-Campos G, Eamus D (2015) Abrupt shifts in phenology and vegetation productivity under climate extremes. JGR Biogeosci 120:2036-2052. https://doi. org/10.1002/2015JG003144

MPNFI (2016) Mongolian multipurpose national forest inventory report (2014-2016). Ministry of Nature and Environment, Ulaanbaatar, p 126
Mühlenberg M, Batkhishig T, Dashzeveg TS, Drößler L, Neusel B, Tsogtbaatar J (2006) Lessons from tree planting initatives in Mongolia. Mongolia Discussion papers, East Asia and Pacific Environment and Social Development Department. World Bank, Washington, p 38. http://documents.worldbank.org/curated/en/ 143891468059947579/pdf/377950MOG0less1ing0P09260901 PUBLIC1.pdf. Accessed 28 Nov 2017

Mühlenberg M, Appelfelder H, Hoffman H, Ayush E, Wilson KJ (2012) Structure of the montane taiga forests of West Khentii, Northern Mongolia. J For Sci 58:45-56

Niemi K, Vuorinen T, Ernstsen A (2002) Ectomycorrhizal fungi and exogenous auxins influence root and mycorrhiza formation of Scots pine hypocotyl cuttings in vitro. Tree Physiol 22(17):1231-1239. https://doi.org/10.1093/treephys/22.17.1231

O'Brien RG (1979) A general ANOVA method for robust tests of additive models for variances. J Am Stat Assoc 74(368):877-880

Oscarsson H, Sigurgeirsson A, Raulund-Rasmussen K (2006) Survival, growth, and nutrition of tree seedlings fertilized at planting on Andisol soils in Iceland: six-year results. For Ecol Manag 229:88-97

Osunkoya OO, Othman FE, Kahar RS (2005) Growth and competition between seedlings of an invasive plantation tree, Acacia mangium, and those of a native Borneo heath-forest species, Melastoma beccarianum. Ecol Res 20(2):205-214

Oyuntuya S, Dorj B, Shurentsetseg B, Bayarjargal E (2015) Agrometeorological information for the adaptation to climate change. In: Badmaev NB, Khutakova CB (eds) Soils of steppe and forest steppe ecosystems of inner Asia and problems of their sustainable utilization: international scientific conference. Buryat State Academy of Agriculture named after V.R. Philipov, UlanUde, pp 135-140

Pawson SM, Brin A, Brockerhoff EG, Lamb D, Payn A, Paquette A, Parrotta JA (2013) Plantation forests, climate change and biodiversity. Biodivers Conserv 22(5):1203-1227

Peel MC, Finlayson BL, McMahon TA (2007) Updated world map of the Köppen-Geiger climate classification. Hydrol Earth Syst Sci Eur Geosci Union 11(5):1633-1644. https://doi.org/10.5194/ hess-11-1633-2007

Pinheiro J, Bates D, DebRoy S, Sarkar D, R Core Team (2018) nlme: linear and nonlinear mixed effects models. R Package version 3.1-137. https://CRAN.R-project.org/package=nlme. Accessed 09 Nov 2017

Pirard R, Secco LD, Russell R (2016) Do timber plantations contribute to forest conservation? Environ Sci Policy 57:122-130

R Development Core Team (2016) R: a language and environment for statistical computing; Version 3.0.2. http://packages.renjin.org/ package/org.renjin.cran/nlme/3.1-113. Accessed 28 Nov 2016

Rammig A, Mahecha MD (2015) Ecosystem responses to climate extremes. Nature 527:315-316

R-bloggers (2011) Linear mixed models. Post by Luis. https://www.rbloggers.com/linear-mixed-models-in-r/. Accessed 24 Nov 2017

Regzedmaa M (2008) Climate resources and changes of meteorological data of Selenge Province. Selenge Press, Sukhbaatar, pp 11-25 (in Mongolian)

Reich PB, Oleksyn J (2008) Climate warming will reduce growth and survival of Scots pine except in the far north. Ecol Lett 11(6):588-597. https://doi.org/10.1111/j.1461-0248.2008.01172.

Robinson AP, Hamann JD (2011) Forest analytics with R-an introduction. Springer, New York, p 354

Saha S, Kühne C, Kohnle U, Bauhus J (2013) Eignung von Nesterund Trupppflanzungen für die Begründung von Eichenbeständen. AFZ-Der Wald 2(2013):37-39 (in German)

Sarkar D (2008) Lattice: multivariate data visualization with R. Springer, New York, p 268 
Schär C, Vidale PL, Lüthi D, Frei C, Häberli C, Liniger MA, Appenzeller C (2004) The role of increasing temperature variability in European summer heatwaves. Nature 427:332-336. https://doi.org/10.1038/nature0230010.1038/ nature 02300

Soehartono T, Newton A, Mardiastuti A (2002) Factors influencing the survival and growth of Aquilaria Malaccensis seedling in Indonesia. J Trop For Sci 14(3):364-378

Tsogtbaatar J (2004) Deforestation and reforestation needs in Mongolia. For Ecol Manag 201(1):57-63

Turtola S, Manninen AM, Rikala R, Kainulainen P (2003) Drought stress alters the concentration on wood terpenoids in Scots pine and Norway Spruce seedlings. J Chem Ecol 29(9):1981-1995. https://doi.org/10.1023/A:1025674116183

Ubugunov VL, Gunin PD, Bazha SN, Drobyshev YuI, Ubugunova VI (2017) Soil desiccation as indicator of desertification of forest- steppe ecosystems in the Barguzin depression. Arid Ecosyst 7(3):142-154

Wang YH, Bonell M, Feger KH, Yu PT, Xiong W, Xu LH (2012) Changing forestry policy by integrating water aspects into forest/ vegetation restoration in dryland areas in China. Bull Chin Acad Sci 26:59-67. http://english.cas.cn/bcas/2012_1/201411/ P020141121533282744018.pdf

Williams AP, Allen CD, Macalady AK (2013) Temperature as a potent driver of regional forest drought stress and tree mortality. Nat Clim Change 3:292-297

Zuur AF, Ieno EN, Walker NJ, Saveliev AA, Smith GM (2009) Mixed effects models and extensions in ecology with $\mathrm{R}$. Springer, New York, p 574

Publisher's Note Springer Nature remains neutral with regard to jurisdictional claims in published maps and institutional affiliations. 